\title{
Exploration Activities Cultural Values Through Learning In Elementary School (Sekolah Dasar Negeri/SDN) Basirih 10
}

\author{
$1^{\text {st }}$ Ersis Warmansyah Abbas* \\ Social Studies Departmet, Faculty of Teacher Training, \\ Lambung Mangkurat University \\ ersiswa@ulm.ac.id
}

\begin{abstract}
The formation of the human character is not done within a short time. A necessary process that must pass them through the educational process. The formation of the characters can be exploited through cultural inheritance for every element of society. One of them is by digging the cultural values of society. This study aims to 1) Describe the cultural values that arise from community activities in Jelai riverbank, 2) Describe the contribution of the cultural values with the pattern of interaction of teachers and students at SDN Basirih 10. Qualitative approach used in the study. Data collection techniques include; interviews, observation, and documentation. Data analysis started with the reduction, presentation, and verification of data. The results of the study described the cultural value that appears there are three. The cultural values are religious values, hard
\end{abstract}

\section{INTRODUCTION}

Education as one of the very important elements in print the next generation, it is still far from the expected. Problems still occur however, the most obvious is the problem of the high cost of education so as not affordable for the lower classes. Supposedly education is the right of all people of Indonesia as contained in the 1945 Constitution which reads one of the objectives of our country is educating the nation. Based on the opening of 1945 has a consequence that the state should organize and facilitate all Indonesian people to obtain proper instruction and education [1], [2]. work, and cooperation. Religious value touches on three dimensions of the Godhead, man, and the universe. The value of hard work appears on the principles of life struggle in practice manifested on hardworking people earn a living for the family to obtain welfare. Value mutual assistance comes in the form of community solidarity in dealings between the members of society although the conditions have to pass through the river to help other people who need help. Contributions of cultural values with the pattern of interaction of teachers and students at SDN Basirih 10 brought about a multi-way interaction. Multidirectional interaction patterns have implications on the emotional closeness that is built up between teachers and learners.

Keywords-Character, Cultural Values, Multi-directional Interaction

Education as a series of processes that will deliver a better life to the side. The education process is what gives hope for us to be able to achieve the expected conditions. We must recognize that education became one of the special energy that can boost the quality of human resources. Through the 12-year compulsory education program can open up opportunities for everyone, hence the need for awareness together to improve the quality of education in our Banua so it will stay awake rhythm of the educational process in the community.

So does that happen in Kampung Sungai Jelai Basirih Village South? The authors admit 
that the Banjarmasin city government has given considerable attention to this village. Banjarmasin city government's seriousness in supporting the 12-year compulsory education program one of them has built a school called SDN Basirih 10.

Basirih State Elementary School 10 is located in Kampung Sungai Jelai RT. 27 Village South Basirih District of South Banjarmasin. If most schools are on land then this school is in the path of the river surrounded by rice fields residents, to get to the school learners and teachers would need access, using river transport in the form of boats and raft. Since time immemorial environmental conditions identical to this river resulted in activities of daily living are very familiar with the river.

The position of the river continues to be undermined by an increase inland transport infrastructure. Practically this be a complicated choice in continuing existence of life with the river's identity as an icon. The need for the formation of character valuesbased culture can introduce learners to their cultural identity, because "When students experience a crisis of cultural values, what happens is a deviation from the nobility and wisdom that characterizes the culture and art in any pattern of life. A society requires education of values for progress. It needs the involvement of family, spiritual community, and school. The role of the school as a place of education is becoming an increasingly important value, especially to provide an understanding that there must be a balance between science and ethics,

However, the formation of human character does not necessarily do in a short period, the need for a process that must pass them through the educational process, in this case, the researchers will examine the scope of social studies education. An important characteristic of IPS education about the various dimensions of human life and is integrated with the various values that characterize life, whether in the family, in society, in the nation and state, as well as in the human relationship with the Creator and the natural environment [3].
Given that the importance of values in education then it should Guru IPS IPS integrate these values because essentially, the value is worth something. Value is a set of beliefs or principles that have behavior in a person or a particular group of people that came to light when thinking or acting. Generally, values learned as a result of interaction or communication between individuals in a group like family, religious community, society or union group for people whose one purpose [4].

Teachers can integrate values in the learning process by making it as a learning resource [5]. Learning resources are all good sources in the form of data, people and a particular form that can be used by learners in learning, either separately or as a combined making it easier for learners to achieve the learning objectives. Through learning resources for learners to obtain information relating to the subject matter they are studying. Social Sciences are excavated areas of the daily practical life of society. Therefore, the social studies learning and forgetting the people as the source of the object, a field of knowledge that is not grounded in reality are unlikely to achieve the target objectives, and would not meet the demands of society [2]. Based on the exposure IPS use of learning resources can be obtained through a community environment in which there are various activities are wrapped in a value.

\section{METHOD}

Judging from the data type of the research approach used in this study is a qualitative approach. As is the qualitative research is research that aims to understand the phenomenon of what is experienced by research subjects holistically, and by way of description in the form of words and language, in a specific context naturally and by using various scientific methods [6]. Research conducted at the banks of Sungai Jelai Village South Basirih Banjarmasin. This research activity started since accepted research proposals as well as permit the research, which is 13 till May 20, 2019. The object of research is in-depth observations of activity, people (actors), and which is in place 
certain [7]. Sumber of research data is a subject from which the data is obtained [8]. To get the right data, it can determine informants who have the competence and by the needs of the data (purposive). This study aims to determine the learning that is focused on the process undertaken [9]. Based on the research results of research subjects, among others:

Table 2. Name of Research Subjects

\begin{tabular}{llll}
\hline No. & Name & Age & Work \\
\hline 1 & Yuseri & 54 Years & The SDN Basirih 10 \\
\hline 2 & Sanderi & 58 Years & Teacher SDN Basirih 10 \\
\hline 3 & Islamic Naylatul & 10 years & Learners SDN Basirih 10 \\
\hline 4 & Aulia Ridho Putra & 11 years & Learners SDN Basirih 10 \\
\hline 5 & Mahdi & 56 Years & Chairman Rt.27 Simpang Barley \\
\hline 6 & imah & 40 Years & Residents of Simpang Barley (Housewife) \\
\hline \multicolumn{2}{l}{ Source: Researcher (data processed, 2019) } &
\end{tabular}

The data collection technique is a way of what and how the necessary data can be collected so that the final results of the study were able to present a piece of valid and reliable information "[8]. Steps of data collection; 1) observations as well as those involved in a particular situation. This is in order to facilitate researchers to obtain data or information easily and freely, 2) Interviews were conducted in-depth and unstructured to the subject of research with the guidelines that have been made, and study documentation is the data collected through the relics written mainly in the form of archives and including books on the opinion, the argument relating to the investigation of the problem. Researchers as the main instrument for only researchers who can act as a tool available and responsive to reality because it is complex. Data analysis techniques used Miles and Huberman models: 1) Reduction of data since data collection began by summarizing, encodes, 2) Data Presentation narrative text form, and 3) Verification and concluding there was activity analysis of existing data. Test the validity of the data in this study using a test of the credibility of the data (internal validity), among others, carried out Triangulation is defined as checking data from various sources in various ways, and various times. and 3) Verification and concluding there was activity analysis of existing data. Test the validity of the data in this study using a test of the credibility of the data (internal validity), among others, carried out Triangulation is defined as checking data from various sources in various ways, and various times. and 3) Verification and concluding there was activity analysis of existing data. Test the validity of the data in this study using a test of the credibility of the data (internal validity), among others, carried out Triangulation is defined as checking data from various sources in various ways, and various times.

\section{RESULTS AND DISCUSSION}

\section{Learning conditions SDN Basirih $\mathbf{1 0}$}

Meanings of education elaborated as activities organized, planned and take place continuously throughout life. The main purpose of education is the intellectual and emotional development of learners perfectly. This is certainly not only be seen as individuals with high intellectual but also making cultured. Achievement of coaching based on the orientation of education on all aspects of the development potential of learners, such as: cognitive, affective, which has implications for the psychomotor.

For learners, learning is a process of interaction between various potential. Learning activities include teacher-learner interaction, the learning environment and learning resources (Permendikbud No. 103 the Year 2014, Article 1). Therefore, the model 
must be innovative and constructive learning. In practice educators must understand the characteristics of the subject matter, the characteristics of learners and learning methods vary. The issue of the note, with regard to innovative learning effort, and constructive, namely: a) stimulating classroom situation freely (not unidirectional and bound); b) teachers as directors; c) teachers as providers of facilities; d) the teacher as motivator and initiator; and e) the teacher to evaluate learning.

Concerning education at the primary school level, it is heavily influenced by the characteristics of learners. Learners primary school age dominated by the desire to play, curiosity, easily affected environment, and likes to establish a peer group. Therefore, learning in primary schools endeavored to create a conducive atmosphere and fun. Factual within the context of learning in a primary school in 2013 designed thematic curriculum. Thematic learning is the integration between subjects so that more meaningful. Surely thematic learning should be supported by optimizing the use of instructional media.

Integrated learning is learning that begins with a subject or theme that is linked to another subject. The existence of the concept of being a unifying interdisciplinary (field) that is taught is practiced in a planned manner. In the learning process, the learner is directed to be personalized intelligent, responsible, tolerant, open, curious and responsible. Factually based on the observation on May 11, 2019 learning in Basirih SDN 10 has implemented in 2013 in the learning curriculum. But it is undeniable that the practice is still far from ideal criteria. This is due to the lack of infrastructure and human resources.

Normally the school is located in the land. However, the existence of SDN Basirih 10 distinctive because in South Basirih Jelai River flow. Basirih SDN 10 is located at Jalan Sungai Jelai RT. 27 South Basirih Village, District of South Banjarmasin, Zip Code 70245. School Building green with a length of 33.2 meters, 22 meters wide with a land area of $45 \times 45$ meters. School buildings forming the letter "L" which has a schoolyard to construct a moist soil and low (in case of pairs then the page is inundated by water). It has six classrooms, teacher offices, WC school, school shop, as well as the schoolyard used for flag ceremonies and other school activities.

Current conditions, learners who study in SDN Basirih 10 is dominated by people who live in Kampung Sungai Jelai RT.27. Based on data from the learning year 2015-2016 the number of learners enrolled from grade 1 to grade 6 by 77 learners. Concerning learning, if specified in the profile of the school was held in the morning at 07.45 WITA until 12:55 pm, but in fact, sometimes learning begins at 08.30 pm until $12.00 \mathrm{pm}$. This could occur due to the presence of SDN Basirih 10 highly dependent on natural conditions in which the clock learns to adapt to conditions of the tidal river.

Every day, the activities of learners start with cleaning the classroom. Cleanliness size class into the start of learning by teachers. Learning begins with the reading of prayers learned, saying Pancasila symbol along and check attendance then enters the core activities, namely teaching the material. In addition to teaching and learning activities, and the schools also hold some religious activities such as Friday piety.

Friday taqwa activities conducted every month. The activities consist of Tadarus Qur'an, Sholawat and Yasinan. All the students gathered in a classroom with teachers to perform Friday taqwa which begins in the morning at 08.30 to finish. After completion of school activities to facilitate the students to perform Infaq donations collected for later donated to the mosque.

In addition to Friday piety, religious activities are performed as the celebration of holy days of Islam among the Prophet's Birthday, Ascension and the Day of Ashura. On the day of Ashura, the school usually held cook porridge with students and parents of students. Religious activity is used as a medium of communication between teachers and learners to strengthen religious knowledge. Religious knowledge learners are expected to make robust to the establishment. 
Thus, as early as possible learners realize that everyday life is the process of sorting out where the good-bad, right-wrong in the mix and socialize. Then, to reinforce the physical dexterity SDN Basirih 10 held healthy Friday. Healthy Friday activities conducted in the form of gymnastics with the teachers and learners. But this exercise is done in the classroom, since the school grounds that are usually flooded by water. However, this did not dampen the enthusiasm of students to participate.

2. Contributions Values Culture and Interaction Patterns between Educators and Students at SDN Basirih 10

\section{a. Rivers and Community Cultural Values in Jelai Riverbank}

The river is a boon for the people of Banjar, especially for people in South Basirih Jelai riverbank. Rivers become vital for transport lines. Of course, the river is not only used for the fulfillment of their daily needs, but also transportation for farming, gardening, trade, fishing, going to work, going to the market, go to community activities and even goes to school, and so on. The waterway is the main
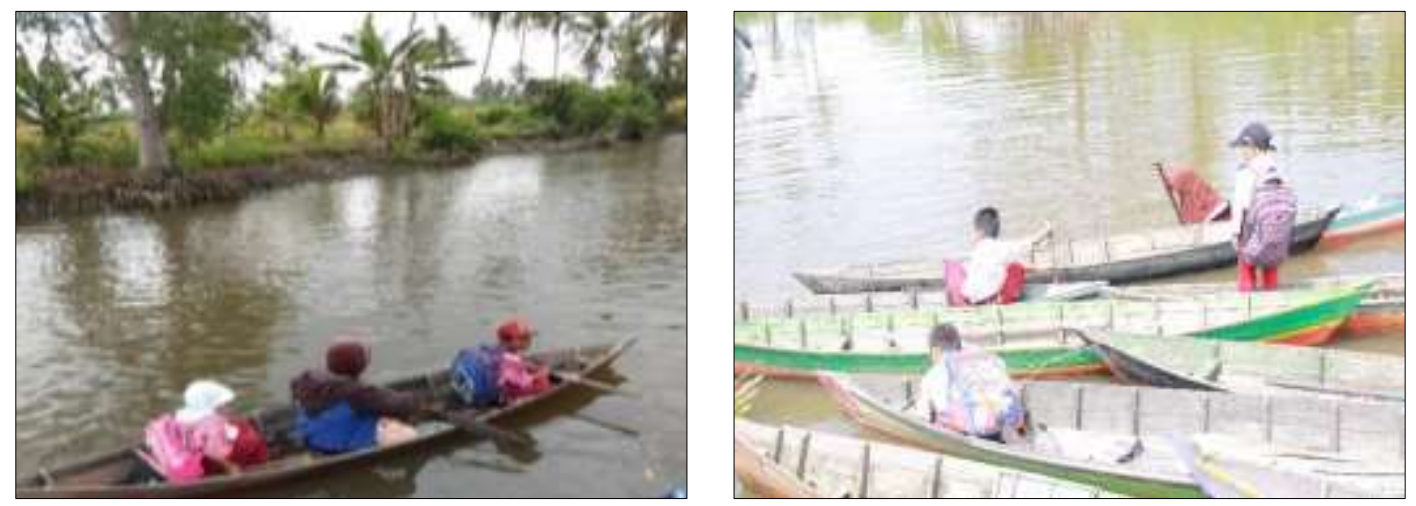

Figure 2. Use of Jukung to the Community in the Jelai Riverbank Source: Personal Documentation (May 2019)

Another condition is partially boarded Klotok reserved for teachers. For those who come to raft teachers, usually, they wait at the departure point is close to the big bridge Basirih. Carrying Klotok can reach 20 people, consisting of seven teachers and 13 learners. Activities that occur in the Jelai River not only the range of routine in SDN Basirih 10. However, distinctiveness very visible in everyday society. Barley riverbank commu- alternative to the SDN Basirih 10. To reach the necessary goal of water transport modes such as boats or rafts. Jukung is the mode of transport used by rowing their way. Capacity was little. Jukung was only able to accommodate a maximum of three (3) adults. While Klotok is water transport modes that have premium fueled engines. Klotok capacity also varies greatly depending on the needs of its users (ranging from 5-15 adults).

Most people who go to school rowboat to paddle their way, or delivered at parents. For learners who rowed themselves usually boarded by three people, who paddled not only the oldest old, that are smaller can also paddle because they are accustomed to using catamarans. For those who escorted the parents are usually still grading 1-3 because they are not used, and parents also fear that the boats could wreck (sunk). Basically riverbank communities in Jelai very familiar with the natural conditions. River instead of a visualization environment that is capable of threatening physical learners. Instead, the river has a vital function for them early on. Here's an overview of how learners' own paddling their boats to SDN Basirih 10. nity, in general, has one boat normally used every day. On Monday to Saturday, the boats used to take the kids to school, or go to the field on Sunday. Jukung likened motor vehicles used to visit the neighbor's house, go to marriage and death. This is because the boats are not cheaper and do not require fuel as Klotok. 
In addition to household activities of everyday life, people often participate actively in urban South Basirih in some activities. The main activities are followed by community religious activities. Some religious activities contained in the Village of South Basirih including reading Al-Qur'an in Sungai Jelai Village. This recitation is composed of the assembly of men held on Monday night, and the congregation of women on Sunday afternoon at 14.00, and if the teen Sunday night Maulid Ethiopia's hometown implement each finished Maghrib to Isha housed violated (mosque).

The children's activity Jelai River starting from the morning, where every morning before going to school they washed into the river, bathing in a trunk, accompanied by their parents, or children who are older bathe themselves while Balumba (swimming) in the river. After bathing them straight to the home because considering the position of the house is very close to the river that is in front of the house.

The vitality of the river that used to daily life produces complex human interaction awakened. Besides, the yield river culture or culture of people who are affected by the environment of the river. Understanding the culture of the river include ways of life, behavior, and adaptations of people who live by the river, it has become a tradition practiced for generations. The formation of the concentration of population settlement patterns berbanjar along river banks, the primary factor is the river. A river for residents who live in the river banks was able to meet and sustain their lives, both from the aspect of transportation and mobility, economic, social, cultural, and political [10]. From the concentration of people and their interaction with the river, the river culture was born.

Conceptually culture has always boiled down to the values taken by the community. Then set value is known as the cultural values. Cultural value is a concept of community ideas and thoughts about what is considered valuable, precious so it can serve as guidelines that give direction to people's lives better and meaningful. Cultural values can be seen in the pattern of activity, whether human relationship with God, man's relationship with nature, human relationships with the community, as well as man's relationship with himself [11]. Cultural values can influence the behavior related to nature, the place of humanity in nature, the relationship of the people and about the things that are desirable and undesirable, that may be related to the relationship of people with the environment and human beings [11], [12]. Cultural values used as guidelines and instructions in the act and act, individually, group or society as a whole about the good and bad, wrong, improper or inappropriate.

Reflecting the opinions Idwar [10] and the conception of cultural values by [11], [12] in the context of the smaller communities in riverbank communities Jelai culture-based streams. This is due to obvious physical environments and all activities undertaken are always oriented to the river, such: housing, schools, transportation routes, transportation modes. Therefore, based on the results of research there are three cultural values found in South Basirih Jelai River community. These three values are presented as follows:

\section{a) Religious Values}

Religious value is a value that reflects devotion to God Almighty. Value can be applied in the form of carrying out the teachings of religion, as well as to exercise of worship [13]. Religious value includes the three-dimensional relationships well as the individual's relationship with God, with other people, and people with nature universal (Environment) [14], [15]. Religious values are all thoughts, words, and actions of a person who strived always based values of divinity and/or teachings of religion [16], [17].

Religious value reflected in the three dimensions of the relationship (God, man, and the universe) as seen from public activity. The first dimension is the relation God head community The Jelai river bank is very enthusiastic to participate in religious activities. A show sincerity to improve closeness to the Almighty. It is embedded 
early on through the family, and schools. For parents there teaching activities/Yasinan held every Monday evening and Sunday afternoon. Religious activity is implemented as a gathering place among the residents, as well as the manifestation of their gratitude for the blessings that have been received so far. Besides the simplest form is to hold salvation that Allah provides sustenance safety and sufficiency for their family life.

In children visible while in schools like every start learning in the classroom of learners first read Tadarus prayers and short verses. Besides, there are routine activities performed taqwa Friday of each month, as well as warning the great days of Islam.

Second, the dimensions of human relations can be seen from the adhesiveness of the existing social system in society Barley riverbank. Cohesion social system mentioned manifested in social care attitude. In particular, people who are unfortunate death. Where compound people do sympathy in residence grieving family. Despite the distance, the community still participate pray, and buried with the rivers and use Klotok.

Third, the dimensions of the universe can be seen from the relation simplicity wise in treating people and the environment. In particular, can be seen from the house on the banks of Sungai Jelai. The house is made of wood but not a permanent structure with the shape of a house on stilts. This is because of the condition of the tidal river to minimize flooding. Additionally, building construction house located at the edge of the river requires a separate calculation in the making. Moreover, if the position slightly protrudes into the middle. Of course not only take into account the buffer pillar of strength in supporting the load of the building, but also the movement of the river water is constantly moving and can cause erosion. Therefore, people on a riverbank using only barley ironwood (ironwood) asFoundation House.

\section{b) Hard work}

Hard work is a form of behavior exhibited by a person in trying persistently trying in earnest to overcome various obstacles to complete the task as well as possible [18]. Citing his opinion Bustamam Ismail [19] that the hard-working attitude and strive to change fate, diligent and earnest in doing the work is the advice for the human and religious obligation of Islam. Religion is a source of motivation and movement as well as the dynamics in the realization of the work ethic. Islam tells them to work and change their destiny. A person must strive and endeavor for the welfare and happiness of each. Indeed the only man capable of trying, working hard and sincerely to be an accomplishment,

In view [20] Working hard is an indispensable virtue. Nothing can replace the work in life. Work hardcovers initiative, perseverance, goal setting, and ingenuity. Without virtues that form good character, people can not live a happy and no society can function effectively. Without good character, the entire human race can not make progress towards a world that upholds the dignity and worth of every person.

The principle of life struggle in practice manifested on hard-working people who earn a living for the family to obtain welfare. Among the forms of behavior hard work in people's daily lives Jelai River South Basirih like some of the people who every day make a living with the intention to meet the needs of family life, including conducted by Norita (35) and her husband, who every day go to trade sell coconut garden produce to market using Klotok Gulf oysters. Besides, most of the youth village also worked as a longshoreman every day from morning until late afternoon.

Not only the looks of adult behavior, but hard work behavior is also reflected in children's self in Sungai Jelai South Basirih namely learners SDN Basirih 10. They tried diligently and earnestly to realize their hopes to get an education. Learners every day paddling boats to take up to 20 minutes to get to school, learners often leak and make them have to stop once to repair the boats they use. Unlike the raft used by teachers who often have damage to the machine, so Klotok used must be tilted. It thus can show their hard work during school at SDN Basirih 10. 


\section{c) Mutual cooperation}

Mutual cooperation is an act appreciated the spirit of cooperation and work together to solve problems together, establish communication and friendship, give relief/aid to people in need. Sub Value mutual assistance among others respect, cooperation, inclusiveness, commitment to a joint decision, consensus, mutual help, solidarity, empathy, anti-discrimination, anti-violence, and the attitude of volunteerism [15].

[11] states on the basis of mutual aid that human beings can not live alone; in essence are dependent on each other; wherever possible someone trying to maintain good relations with each other; and someone is always trying to compromise, do the same and together with others in the community, driven by the same spirit at a low height.

Mutual cooperation is also associated with cultural values in human relationships with people associated with the interests of the members of society, not the values that are considered important in a society member, as an individual as a person. Preferred interests in the group or community are togetherness.

In South Basirih Jelai River community, community activities such as gotong-royong can be found at the time of the marriage ceremony. Jelai River community which conducts the marriage very clutching mutual assistance are applied in the division of civic duty male and female citizens. Community solidarity in dealings between the members of society although the conditions have to pass through the river, people keep in touch and assist people in need.

Generally, for the community of mutual cooperation behavior can be seen at weddings. everyone gets the duty to assist the families who have urination. While the behavior of mutual assistance for the children seen the beginning of each school SDN Basirih 10 was built on the initiative of a teacher at SDN Basirih 1 at that time Mr. Syamsuripai, then there are the people who donated the land to serve as the construction of schools, since at that time the schools with Jelai River farthest settlement, and therefore they jointly worked together to build SDN Basirih 10.

\section{b. Interaction Patterns Multi Directions Educators and Learners At SDN Basirih 10}

The said pattern is defined in the Dictionary of Indonesian (KBBI) pattern is "images, patterns, models, systems, mechanisms, shape, and structure" (MONE, 2008). Said interaction interpret as an action, touch, affect, and interrelationships. Interaction is the dynamic relationships concerning the relationship between the individual-individual, individual-group and between groups of people [21]. The word "pattern" and "interaction" linked to one concept into a different definition.

Patterns of interaction are synthesized as a basic form of individual communication with individuals or groups of individuals with groups or with individuals to provide feedback between the parties to one another with the intent or certain things to achieve the goal. Obviously, such communications are interrelated. As for the relation with multidirectional interaction patterns educator (teacher) and learners at SDN Basirih, 10 is a pattern of interaction that is instructive. Said to be educative for resting on the goal of providing education (educate) learners.

Learning as described in the sub-second discussion was the activity of human interaction between the two elements, namely; teachers and learners. Teachers as educators and learners as a subject of study [22]. Learning as a process of interaction means putting the teacher not as a source of learning, but as an environmental regulator or regulatory interaction itself [23].

Teachers as educators should try to turn on and provide motivation for a process of educational interaction conducive. Teachers must be prepared as a mediator in all situations. This is because the teacher is a role model for students. Based on the findings, the pattern of teacher interaction with students in the learning of communication as a transaction or multidirectional. Multi-directional communication requires more active learners rather than teachers [24]. Multidirectional interaction 
means that teachers and learners are mutually provided a response in the interaction among learners have the opportunity to interact not deviate from teaching materials [25]. Multidirectional interaction has implications for the emotional closeness that is built up between teachers and learners. Multidirectional interaction patterns that occur tend to make the learning activities smoothly without a hitch despite the fact hampered by limited infrastructure. SDN Basirih 10 teachers not only as a teacher but also a motivator in giving color to learning. Multidirectional interaction patterns also provide space for teachers at SDN Basirih 10 to continue to innovate in learning. Thus, teachers often take advantage of the environment as a solution. Multidirectional interaction patterns also provide space for teachers at SDN Basirih 10 to continue to innovate in learning. Thus, teachers often take advantage of the environment as a solution. Multidirectional interaction patterns also provide space for teachers at SDN Basirih 10 to continue to innovate in learning. Thus, teachers often take advantage of the environment as a solution [26].

\section{CONCLUSIONS}

South Basirih Jelai River is a village located on the outskirts of the city of Banjarmasin, where the village is still keeping local authenticity that characterizes the city of Banjarmasin. People living form riverbank settlements in Jelai. In particular society at Jelai river bank raises cultural values inherent in everyday activities. These values are religious, hard work, and cooperation. Religious value touches on three dimensions of the Godhead, man, and the universe. The value of hard work appears on the principles of life struggle in practice manifested on hardworking people earn a living for the family to obtain welfare.

Contributions of cultural values with the pattern of interaction of teachers and students at SDN Basirih 10 brought about a multi-way interaction. Multidirectional interaction patterns have implications on the emotional closeness that is built up between teachers and learners. Multidirectional interaction patterns that occur tend to make the learning activities smoothly without a hitch despite the fact hampered by limited infrastructure. SDN Basirih 10 teachers not only as a teacher but also a motivator in giving color to learning. Multidirectional interaction patterns also provide space for teachers at SDN Basirih 10 to continue to innovate in learning.

\section{ACKNOWLEDGMENTS}

The researcher would like to thank to everyone who involved in this research.

\section{REFERENCES}

[1] M. Mutiani. (2015). Pemanfaatan Puisi Sebagai Sumber Belajar IPS Untuk Menumbuhkan Kesadaran Lingkungan Peserta Didik di SMP Negeri 6 Banjarmasin. J. Pendidik. ILMU Sos., 24(2), pp.199-208.doi: 10.17509/jpis.v24i2.1456.

[2] M. Mutiani. (2015). Reaktualisasi Pengamalan Nilai Pancasila untuk Demokrasi Indonesia. Sosio-Didakt. Soc. Sci. Educ. J., 2(2), pp. 176-183. doi: 10.15408/sd.v2i2. 2822.

[3] M. Mutiani. (2017). IPS dan Pendidikan Lingkungan: Urgensi Pengembangan Sikap Kesadaran Lingkungan Peserta Didik. SOSIO-Didakt. Soc. Sci. Educ. J., 4(1). pp. 45-53-53. doi: 10.15408/sd. v4i1.5718.

[4] Sapriya. (2017). Pendidikan IPS Konsep dan Pembelajaran, Cetakan 8. Bandung: PT. Remaja Rosdakarya.

[5] E. W. abbas, M. Mutiani, dan D. S. Nugraha. (2018). Social Values in Zainal Ilmi Biography as learning Source of social Studies. 3rd ISSSHE Int. Semin. Sos. Stud. Hist. Educ. Promot. 21st Century Ski. Soc. Stud. Learn.

[6] Lexy J. Moleong dan Tjun Surjaman. (2010). Metodologi penelitian kualitatif. Bandung: Remaja Rosdakarya.

[7] Sugiyono. (2017). Metode Penelitian Kuantitatif, Kualitatif, dan RED. Bandung: Alfabeta. 
[8] A. Suharsimi. (2004). Prosedur Penelitian Suatu Pendekatan Praktek, Edisi. Kelima. Jakarta: Rineka Cipta.

[9] B. Bungin. (2015). Metodologi penelitian kualitatif: Aktualisasi metodologis Kearah Ragam Varian Kontemporer, Ed.1, Cet.ke-8. Jakarta: Rajawali Pers.

[10] M. I. Saleh. (1983). Sekilas mengenai Daerah Banjar dan kebudayaan Sungainya sampai dengan akhir Abad-19. Banjarbaru: Departemen Pendidikan dan Kebudayaan, Direktorat Jenderal Kebudayaan, Proyek Pengembangan Permuseuman Kalimantan Selatan: Museum Negeri Lambung Mangkurat Propinsi Kalimantan Selatan.

[11] Koentjaraningrat. (2009). Pengantar Ilmu Antropologi. Jakarta: Rineka Cipta.

[12] B. Subiyakto. (2005). Menjadikan Sungai Sebagai Objek Studi. J. Kandil Ed, Tahun III Mei-Juli.

[13] E. W. Abbas dan I. Rajiani. (2017). A New Creative Model of Da'wah as a Medium of Economic Development in Indonesia. Varazdin Dev. Entrep. Agency VADEA, pp. 302-306.

[14] Kemendikbud. (2016). Permendikbud No. 020 Tahun 2016 Tentang Standar Kompetensi Lulusan Pendidikan Dasar dan Menengah.

[15] Kemendikbud. (2017). Panduan Penilaian oleh Pendidik dan Satuan Pendidikan untuk Sekolah Menengah Atas. Direktorat Jenderal Pendidikan Dasar dan Menengah.

[16] D. Mulyana. (2001). Metodelogi Penelitian Kualitatif: Paradigma Baru Ilmu Komunikasi dan Ilmu Sosial Lainnya. Bandung: Remaja Rosdakarya.

[17] R. Mulyana. (2004). Mengartikulasikan Pendidikan Nilai, Cet. Ke-1. Bandung: Alfabeta.

[18] M. Mustari dan M. T. Rahman. (2011). Nilai Karakter: Refleksi untuk Pendidikan Karakter, vol. 1, No. 1. Yogyakarta: Laksbang Pressindo.

[19] H. Mulyawati, Ed. (2010). Pembelajaran Studi Sosial: tujuan Pengajaran Studi Sosial, Mendidik Anak menjadi Warga Negara yang Baik, Cet. 1. Bandung: Alfabeta.

[20] T. Lickona dan J. A. Wamaungo. (2015). Educating For Character: Mendidik untuk Membentuk Karakter: Bagaimana Sekolah dapat Memberikan Pendidikan tentang Sikap Hormat dan Bertanggung Jawab. Jakarta: PT. Bumi Aksara.

[21] S. Soekanto. (2014). Sosiologi Suatu Pengantar. Jakarta: Raja Grafindo Persada.

[22] Sardiman AM. (2011). Interaksi dan Motivasi Belajar Mengajar. Jakarta: Rajawali Pers.

[23] A. Majid. (2013). Strategi Pembelajaran, Cetakan 1. Bandung: PT. Remaja Rosdakarya.

[24] M. U. Usman. (1999). Menjadi guru profesional. PT. Remaja Rosdakarya.

[25] Y. Nuni. (2013). Desain Relasi Efektif Guru dan Murid. Buku Baru.

[26] Depdiknas. (2008). Kamus Besar Bahasa Indonesia. Gramedia Pustaka Utama. 